\title{
Comparison of the Analgesic Activity of Antiparkinsonian Aminoadamantane Derivatives Amantadine and Hemantane
}

\author{
Elena Ivanova*, Inga Kapitsa, Elena Valdman, Tatyana Voronina \\ Laboratory of Psychopharmacology, Zakusov Institute of Pharmacology, Moscow, Russia \\ Email: "iwanowaea@yandex.ru
}

Received 11 July 2016; accepted 7 August 2016; published 11 August 2016

Copyright ( 2016 by authors and Scientific Research Publishing Inc.

This work is licensed under the Creative Commons Attribution International License (CC BY).

http://creativecommons.org/licenses/by/4.0/

(c) $\underset{\mathrm{EY}}{\mathrm{EY}}$ Open Access

\begin{abstract}
The efficacy of some aminoadamantane derivatives used as neurodegeneration treatments is due to their ability to block NMDA receptors. But this mechanism of pharmacological action can also produce analgesic activity. Analgesic properties of two aminoadamantanes, amantadine (20 $\mathrm{mg} / \mathrm{kg}$ ) and hemantane $(20 \mathrm{mg} / \mathrm{kg})$, which were uncompetitive NMDA receptor antagonists, were assessed in rodent models of pain induced by different pain stimuli (tail-flick test, acetic twitches test in mice and formalin test in rats). Additionally, the anti-inflammatory properties of hemantane and amantadine were evaluated in mice with acetic peritonitis and in rats with hind paw edema induced by formalin injection. The results of our study demonstrate that the analgesic activity of the 1-aminoadamantane amantadine differs from the 2-aminoadamantane hemantane. The analgesic activity of amantadine administered intraperitoneally was more pronounced in the case of acute thermal pain in mice compared to hemantane, and only amantadine had a significant analgesic effect on the acute early phase of formalin pain in rats induced by the effect of the algogen on the primary sensory afferents. Hemantane was more effective than amantadine for relieving pain produced by inflammation owing to its pronounced anti-inflammatory activity: only hemantane decreased the amount of acetic twitches in mice that received drugs orally and was effective in the tonic phase of formalin pain in rats.
\end{abstract}

\section{Keywords}

NMDA Receptor Antagonists, Tail-Flick Test, Acetic Twitches, Formalin Test, Exudative Inflammation

\footnotetext{
${ }^{*}$ Corresponding author.
}

How to cite this paper: Ivanova, E., Kapitsa, I., Valdman, E. and Voronina, T. (2016) Comparison of the Analgesic Activity of Antiparkinsonian Aminoadamantane Derivatives Amantadine and Hemantane. Advances in Parkinson's Disease, 5, 50-60. 


\section{Introduction}

Some derivatives of aminoadamantane are known as efficient treatments for neurodegenerative diseases [1]. Amantadine, a derivative of 1-aminoadamantane, is useful as an antiparkinsonian and antidyskinetic drug [2]-[4]. Benefits of therapy with memantine, another 1-aminoadamantane, are confirmed in clinical trials investigating the treatment of Alzheimer's disease [5] [6], vascular dementia [7], and Parkinson's disease [8]. Hemantane, a derivative of 2-aminoadamantane, is a new antiparkinsonian and antidyskinetic agent [9] [10] and currently undergoing clinical trials in the Russian Federation.

The aminoadamantane derivatives act by blocking NMDA receptors [11]-[13]. In addition to the neuroprotective effect, the blocking of NMDA receptors could also produce analgesic activity [14]. Activation of NMDAtype ionotropic glutamate receptors is required for long-term potentiation of nociceptive neurons [15]-[17] and plays a major role in the amplification of a nociceptive input in post-inflammatory conditions [18].

The analgesic effect of the NMDA receptor antagonist amantadine, a 1-aminoadamantane, was demonstrated in patients with diabetic peripheral neuropathy [19]. Another NMDA receptor antagonist, hemantane, a 2-aminoadamantane, demonstrated analgesic properties in the model of visceral pain in mice [20].

The goal of this study is to compare the analgesic effects of the 1-aminoadamantane amantadine and 2-aminoadamantane hemantane in rodent models of pain induced by different pain stimuli.

Amantadine (adamantan-1-amine) is used in two salt forms: amantadine hydrochloride [3] and sulfate [21]. In our work amantadine hydrochloride was used because hemantane was also a hydrochloride, specifically $\mathrm{N}-2$ (adamantyl) hexamethylenimine hydrochloride (Figure 1). Comparator drugs were used to objectively assess the analgesic effects of amantadine and hemantane on pain in rodents. Carbamazepine, an anticonvulsant, was used as an effective comparison drug in models of peripheral thermal nociception [22]. Diclofenac sodium, an extensively used and highly effective nonsteroidal anti-inflammatory drug (NSAID) [23]-[25], was used in models of inflammation-induced pain and in additional experiments on exudative inflammation.

\section{Materials and Methods}

\subsection{Animals}

Male white outbred rats weighing 240 to $295 \mathrm{~g}$ at the age of 2.5 months and male white outbred mice weighing 27 to $30 \mathrm{~g}$ at the age of 2 months were obtained from the Stolbovaya branch of the Scientific Centre of Biomedical Technology of Federal Biomedical Agency (Moscow Region, Russia). Mice were used in the tail-flick test and the acetic twitches test; the formalin test was done in rats. Animals were housed under standard conditions: constant temperature $\left(22^{\circ} \mathrm{C} \pm 1{ }^{\circ} \mathrm{C}\right)$, humidity (relative, $30 \%$ ) and a $12 \mathrm{~h}$ light/dark cycle and were allowed to adapt to the laboratory conditions for 7 days before the onset of the experiments. The use of the animals and protocol procedures were approved and supervised by the Ethics Committee for the Use of Laboratory Animals at the Zakusov Institute of Pharmacology, Moscow, Russia.

\subsection{Drugs under Investigation}

Amantadine and hemantane were synthesized in the department of experimental technology of the Zakusov Institute of Pharmacology under the direction of the leading researcher Dr. N.I. Avdyunina. The compounds were administered at the dose of $20 \mathrm{mg} / \mathrm{kg}$. Determination of the dose was based on previous experimental results. Hemantane at the dose of $20 \mathrm{mg} / \mathrm{kg}$ demonstrated analgesic and anti-inflammatory properties in mice [20]. Amantadine at the dose of $20 \mathrm{mg} / \mathrm{kg}$ exhibited antiparkinsonian action in some animal models of Parkinson's

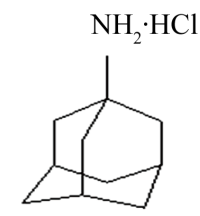

Amantadine hydrochloride

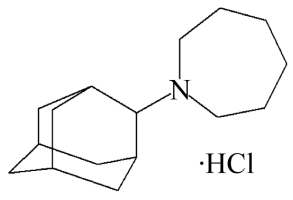

Hemantane

Figure 1. Structural formulas of the 1-aminoadamantane amantadine and 2aminoadamantane hemantane. 
disease [26] [27]. The dose of the comparator drug carbamazepine produced by ALSI Pharma (Russia) was determined in our preliminary results at $20 \mathrm{mg} / \mathrm{kg}$, identical with the dose of aminoadamantanes under inverstigation. The comparator drug diclofenac sodium produced by Hemofarm (Serbia) was administered at the dose of $10 \mathrm{mg} / \mathrm{kg}$. Determination of the dose of diclofenac sodium is based on literature [28] [29] and our previous results.

\subsection{The Tail-Flick Test}

The tail-flick test was used as a model of acute thermal pain in mice [30]. The tail-flick response was tested using a TSE Systems tail-flick apparatus (Germany). A thermal stimulus was applied at a 25\% intensity, which corresponds to a temperature of $50^{\circ} \mathrm{C}$ to $55^{\circ} \mathrm{C}$. This temperature produces tail-flick latencies of 4 to 5 sec while preventing tissue damage. In the absence of a withdrawal reflex, the stimulus was cut off at 10 sec to avoid possible tissue damage [31]. Experimental animals were divided into four groups of 10 mice each: control group, hemantane group, amantadine group and group of the comparison drug carbamazepine. Tail-flick latencies were evaluated 30, 60 and $90 \mathrm{~min}$ after an injection of hemantane $(20 \mathrm{mg} / \mathrm{kg})$, amantadine $(20 \mathrm{mg} / \mathrm{kg})$, carbamazepine (20 mg/kg) or saline (control group) intraperitoneally (i.p.).

\subsection{The Acetic Twitches Test}

The model of acetic twitches in mice was chosen as a model of persistent pain produced by acute inflammation. Twitches were induced by an i.p. injection of $1 \%$ acetic acid, $1 \mathrm{ml}$ per $100 \mathrm{~g}$ of animal weight, and were counted for $15 \mathrm{~min}$ after the injection [32]. Mice were divided into 4 groups of 12 mice each. 40 minutes before the acetic acid injection, animals of the control group were given saline i.p.; mice of the comparison drug group received the NSAID diclofenac sodium i.p. $10 \mathrm{mg} / \mathrm{kg}$, mice of the third group received hemantane i.p. $20 \mathrm{mg} / \mathrm{kg}$, and mice of the fourth group received amantadine i.p. $20 \mathrm{mg} / \mathrm{kg}$.

\subsection{Evaluation of Exudative Inflammation in Mice after Acetic Acid Injection}

Exudate from the abdominal cavity of mice was collected at 3 hours after the i.p. acetic acid injection, and its amount was measured in order to compare the anti-inflammatory effect of hemantane with amantadine and diclofenac sodium [32].

\subsection{Evaluation of the Analgesic Activity of Oral Hemantane and Amantadine in Mice}

Two additional experiments were performed to evaluate the analgesic activity of oral hemantane and amantadine. The tail-flick test and acetic twitches test in mice were described above. Control group animals were given oral saline; mice of the second group received oral hemantane $20 \mathrm{mg} / \mathrm{kg}$, and mice of the third group received oral amantadine $20 \mathrm{mg} / \mathrm{kg} 40$ minutes before the tests. There were 8 to 10 animals in each experimental group.

\subsection{The Formalin Test}

The formalin test in rats simulates pain produced by surgery dissections and includes two phases of pain behavior: the early acute phase and the late tonic phase [33] [34]. Pain behavior was measured every 5 minutes on a scale from 0 to 4 with the following interpretation 0 : no reaction; 1 : the paw is on the ground but the rat does not stand on it; 2: the paw is raised; 3: the rat is licking, flinching or shaking its paw [30]. Data were recorded in the early acute phase 0 to 5 minutes after the injection of $100 \mu \mathrm{l}$ of a $2 \%$ formalin solution and in the late tonic phase 20 to 60 minutes after the injection [33]. 1 hour before the formalin injection, animals of control group were given saline i.p.; mice of the comparison drug group received diclofenac sodium (Hemofarm, Serbia) i.p. $10 \mathrm{mg} / \mathrm{kg}$; mice of the third group received hemantane i.p. $20 \mathrm{mg} / \mathrm{kg}$; and mice of the fours group received amantadine i.p. $20 \mathrm{mg} / \mathrm{kg}$. There were 8 to 10 animals in each experimental group.

\subsection{Evaluation of Paw Edema in Rats Induced by Formalin Injection}

Additionally, the effect of hemantane, amantadine and diclofenac sodium on test paw edema was recorded. The baseline diameters of the hind paws were measured at the metatarsal level before the formalin injection using a caliper. The diameters of the hind paws that developed edema were determined 4 hours after the injection by 
measuring the dorsal-plantar foot thickness at the metatarsal [31] [33]. An increase in the paw's diameter 4 hours after the formalin injection was a sign of inflammation.

\subsection{Data Analysis}

Statistica 8 software was used to perform statistical analyses. Normality was checked by the Shapiro-Wilk test with further estimation of dispersion congruence using the Levene test. The Newman-Keuls test was used for parametric analysis; the Kruskal-Wallis test with post-hoc Dunn's multiple comparison test and the MannWhitney test were used for non-parametric analysis. Statistical significance was set at $\mathrm{p}<0.05$. Data in the tables and figures are expressed as median, $25 \% \div 75 \%$.

\section{Results}

\subsection{Evaluation of the Analgesic Activity of Intraperitoneal Hemantane and Amantadine in the Tail-Flick Test}

In the model of acute thermal pain, median tail-flick latency in the control group (receiving saline i.p.) was 4.5 4.8 seconds during the 90 minutes of experiment. At 30 and 60 minutes after the administration of hemantane (20 mg/kg i.p.), the median tail-flick latency significantly increased by $10.4 \%$ and $8.5 \%$ compared to the control group ( $<<0.05)$. At 90 minutes there was a 13.3\% tendency $(\mathrm{p}<0.1)$ toward an increase of the pain threshold. The efficacy of amantadine (20 mg/kg i.p.) was more pronounced than hemantane (20 mg/kg i.p.). The tail-flick latency increase relative to the control group was insignificant at $27.1 \%(\mathrm{p}<0.1)$ at 30 minutes after the injection and significant at $14.9 \%$ and $17.8 \%$ at 60 and 90 minutes of observation respectively $(\mathrm{p}<0.05)$. The comparator drug carbamazepine (20 mg/kg i.p.) exhibited the most pronounced analgesic effect in the tail-flick test. It significantly increased pain threshold in mice by $35.4 \%$ at 30 minutes, $42.6 \%$ at 60 minutes and $26.7 \%$ at 90 minutes after the injection compared to the control group ( $<<0.05)$ (Figure 2).

\subsection{Evaluation of the Analgesic Activity of Intraperitoneal Hemantane and Amantadine in the Acetic Twitches Test}

In the model of acetic twitches, the median number of twitches in the control group (saline i.p.) was 54 . Hemantane $(20 \mathrm{mg} / \mathrm{kg})$ significantly reduced pain reaction by $32.4 \%$ compared to the control group $(\mathrm{p}<0.05)$. The effect of amantadine $(20 \mathrm{mg} / \mathrm{kg})$ was similar to hemantane: in the amantadine group the number of twitches dropped by 33.3\% ( $\mathrm{p}<0.05)$. The analgesic activity of both adamantane derivatives did not differ significantly from the effect of the NSAID diclofenac sodium $(10 \mathrm{mg} / \mathrm{kg}$ i.p.), which reduced the median number of twitches by $48.1 \%$ compared to the control group $(\mathrm{p}<0.05)$ (Table 1$)$.

\subsection{Evaluation of the Analgesic Activity of Oral Hemantane and Amantadine in Mice}

Two additional experiments were performed to evaluate the analgesic activity of the adamantane derivatives administered orally in the tail-flick test and acetic twitches test in mice. Hemantane $(20 \mathrm{mg} / \mathrm{kg})$ was found to

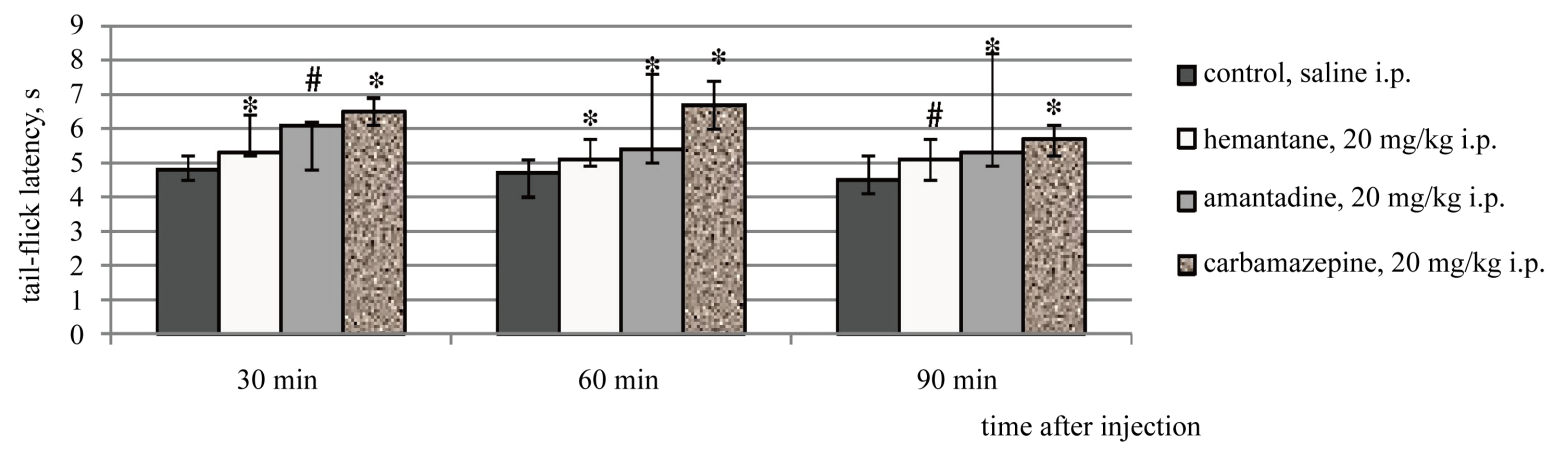

Figure 2. Tail-flick latency at 30, 60 and 90 minutes after injections of hemantane, amantadine, carbamazepine or saline (control group). Data were analyzed by the Mann-Whitney test. Data are expressed as median $(25 \% \div 75 \%)$. ${ }^{*} \mathrm{p}<0.05$ compared to the control group; \# $<0.1$ compared to the control group. 
significantly reduce pain reaction in both tests $(\mathrm{p}<0.05)$. In the tail-flick test the pain threshold in mice receiving hemantane increased by $11.4 \%$ (Table 2 ). In the model of persistent pain produced by acute inflammation, hemantane induced a $28.6 \%$ drop in the number of twitches, and its effect did not significantly differ from the effect of diclofenac sodium (10 mg/kg) (Table 1$)$. Amantadine $(20 \mathrm{mg} / \mathrm{kg}$ ) by administered orally 40 minutes before the experiments failed to exhibit analgesic properties in any of the tests (Table 1 and Table 2).

\subsection{Evaluation of the Analgesic Activity of Intraperitoneal Hemantane and Amantadine in the Formalin Test}

In the formalin test, the maximum pain score in rats of all experimental groups observed at the moment of algogen injection (minute 0); pain reaction decreased at minute 5 of the acute phase. Significant reduction of pain behavior at minute 5 of observation compared to the rats receiving saline was observed only in rats that received amantadine $(20 \mathrm{mg} / \mathrm{kg}$ i.p.) $(\mathrm{p}<0.05)$. Amantadine was the only compound to significantly reduce the average score in the acute early phase of formalin pain by $33.3 \%$ relative to the control group $(p<0.05)$ (Table 3$)$.

Table 1. The number of twitches in mice with acetic peritonitis.

\begin{tabular}{ccc} 
& \multicolumn{2}{c}{ The number of twitches with different routes of administration } \\
\cline { 2 - 3 } & intraperitoneally & orally \\
\hline Control, saline & $54.0(50.0 \div 64.0)$ & $70.0(52.0 \div 84.0)$ \\
Hemantane, $20 \mathrm{mg} / \mathrm{kg}$ & $36.5(24.0 \div 50.0)^{*}$ & $50.0(41.0 \div 53.0) \#$ \\
Amantadine, $20 \mathrm{mg} / \mathrm{kg}$ & $36.0(21.0 \div 47.0)^{*}$ & $74.0(69.0 \div 80.0)$ \\
Diclofenac sodium, $10 \mathrm{mg} / \mathrm{kg}$ & $28.0(17.0 \div 33.0)^{*}$ & $42.0(28.0 \div 58.0) \#$
\end{tabular}

Data were analyzed by the Newman-Keuls test (for parametric analysis) and by the Mann-Whitney test (for non-parametric analysis). Data are expressed as median $(25 \% \div 75 \%)$. ${ }^{p} p<0.05$ compared to the control group, Mann-Whitney test; \#p $<0.05$ compared to the control group, Newman-Keuls test.

Table 2. Tail-flick latency after the oral administration of hemantane, amantadine or saline.

\begin{tabular}{cc}
\hline Control, saline orally & Tail-flick latency (s) \\
Hemantane, $20 \mathrm{mg} / \mathrm{kg}$ orally & $4.4(3.5 \div 4.7)$ \\
Amantadine, $20 \mathrm{mg} / \mathrm{kg}$ orally & $4.9(4.5 \div 5.7)^{*}$ \\
\hline
\end{tabular}

Data were analyzed by the Mann-Whitney test. Data are expressed as median $(25 \% \div 75 \%)$. ${ }^{*} \mathrm{p}<0.05$ compared to the control group.

Table 3. Pain behavior in the acute early phase of the formalin test (score).

\begin{tabular}{cccc}
\hline & \multicolumn{2}{c}{ Time after the formalin injection, min } & Average score \\
\cline { 2 - 3 } & $0 \mathrm{~min}$ & $5 \mathrm{~min}$ & \\
\hline Control, saline & $3.0(3.0 \div 3.0)$ & $1.5(1.0 \div 2.0)$ & $4.5(4.0 \div 5.0)$ \\
Hemantane, $20 \mathrm{mg} / \mathrm{kg}$ & $3.0(3.0 \div 3.0)$ & $1.0(0.0 \div 2.0)$ & $4.0(3.0 \div 5.0)$ \\
Amantadine, $20 \mathrm{mg} / \mathrm{kg}$ & $3.0(2.5 \div 3.0)$ & $0.0(0.0 \div 1.0)^{*}$ & $3.0(3.0 \div 3.5)^{*}$ \\
Diclofenac sodium, $10 \mathrm{mg} / \mathrm{kg}$ & $3.0(3.0 \div 3.0)$ & $1.0(0.0 \div 1.0)$ & $4.0(3.0 \div 4.0)$ \\
\hline
\end{tabular}

Data were analyzed by the Kruskal-Wallis test with post-hoc Dunn's multiple comparison test. Data are expressed as median (25\% $\div 75 \%$ ). ${ }^{*} \mathrm{p}<0.05$ compared to the control group. 
Pain reaction in the control animals reached a peak at minute 20 of the tonic phase, thereafter decreasing gradually up to minute 30 of observation. Specifically, the score was 2.5 at minute 25 and 2 at minute 30 after the formalin injection. The median pain score in the control group was stable from minute 30 to minute 60 of observation. The average score in the tonic phase of formalin pain (from minute 20 to minute 60 after the formalin injection) in the control group was 18.5 (Table 4).

Hemantane (20 mg/kg i.p.) delayed the development of tonic pain by decreasing pain reaction compared to the control group significantly at minute 20 ( $p<0.02$ ) and insignificantly at minute $25(\mathrm{p}<0.3)$. In the diclofenac sodium (10 mg/kg i.p.) group the intensity of pain behavior was also reduced significantly at minutes 20 and 25 of observation $(\mathrm{p}<0.05)$. There were no significant differences between the control group and the groups of rats receiving hemantane or diclofenac sodium at minutes 30 to 60 after the formalin injection (Table 4). The average score for the tonic phase of formalin pain for the hemantane and diclofenac sodium groups decreased significantly $(\mathrm{p}<0.05)$. Hemantane reduced the intensity of pain behavior by $27 \%$; diclofenac sodium, by $30 \%$ compared to the control group (Table 4). The 2-aminoadamantane amantadine $20 \mathrm{mg} / \mathrm{kg}$ failed to produce a significant effect on the tonic phase of formalin pain (Table 4).

\subsection{Evaluation of the Anti-inflammatory Activity of Hemantane and Amantadine in Rats with Paw Edema Induced by Formalin Injection}

After the formalin injection the edema of the damaged hind paw was progressing, and at 4 hours the median paw diameter in the control group increased by $1.2 \mathrm{~mm}$. Hemantane $(20 \mathrm{mg} / \mathrm{kg}$ ) significantly decreased the exudative reaction by $42 \%$ compared to the control group ( $\mathrm{p}<0.05$ ). Its effect was non-inferior to the effect of the NSAID diclofenac sodium $(10 \mathrm{mg} / \mathrm{kg})$, which reduced the edema of the affected hind paw by $17 \%$ relative to the control group ( $<$ 0.05). Amantadine $(20 \mathrm{mg} / \mathrm{kg}$ ) did not exhibit significant anti-inflammatory activity (Figure 3 ).

\subsection{Evaluation of the Anti-Inflammatory Activity of Hemantane and Amantadine in Mice with Peritonitis Induced by Acetic Acid Injection}

Additionally, the anti-inflammatory properties of hemantane were confirmed by measuring the level of peritoneal exudation 3 hours later after the injection of $1 \%$ acetic acid in mice in the acetic twitches test. Hemantane $(20 \mathrm{mg} / \mathrm{kg})$ demonstrated a significant anti-inflammatory effect when administered i.p. and orally $(\mathrm{p}<0.05)$. Intraperitoneal injection of hemantane reduced exudation by a median of $32.8 \%$ compared to the control group. Administration of hemantane $20 \mathrm{mg} / \mathrm{kg}$ orally reduced the intensity of acetic peritonitis by $30.5 \%$ relative to control group animals. The effects of hemantane $(20 \mathrm{mg} / \mathrm{kg}$ i.p.) and orally did not significantly differ from the effects of the comparator drug diclofenac sodium $(10 \mathrm{mg} / \mathrm{kg})$. Intraperitoneal injection of the NSAID reduced inflammation by $60.2 \%(\mathrm{p}<0.005)$, and its oral administration reduced the pathological reaction by $57.4 \%$ ( $<<$ $0.005)$ compared to the control group. The adamantane derivative amantadine $(20 \mathrm{mg} / \mathrm{kg})$ had a significant antiinflammatory effect only when administered i.p. $(\mathrm{p}<0.05)$. The medicine exhibited the weakest anti-exudative properties among the compounds under investigation and reduced inflammation by $18.6 \%$ compared to the control group (Table 5).

Table 4. The pain behavior in the late tonic phase of formalin test (score).

\begin{tabular}{|c|c|c|c|c|c|c|c|c|c|c|}
\hline & & & & ime after the & formalin inj & ection, min & & & & Average \\
\hline & $20 \mathrm{~min}$ & $25 \mathrm{~min}$ & $30 \mathrm{~min}$ & $35 \mathrm{~min}$ & $40 \mathrm{~min}$ & $45 \mathrm{~min}$ & $50 \mathrm{~min}$ & 55 min & $60 \mathrm{~min}$ & \\
\hline $\begin{array}{l}\text { Control, } \\
\text { saline }\end{array}$ & $\begin{array}{c}3.0 \\
(2.0 \div 3.0)\end{array}$ & $\begin{array}{c}2.5 \\
(2.0 \div 3.0)\end{array}$ & $\begin{array}{c}2.0 \\
(2.0 \div 2.0)\end{array}$ & $\begin{array}{c}2.0 \\
(2.0 \div 2.0)\end{array}$ & $\begin{array}{c}2.0 \\
(2.0 \div 2.0)\end{array}$ & $\begin{array}{c}2.0 \\
(2.0 \div 2.0)\end{array}$ & $\begin{array}{c}2.0 \\
(2.0 \div 2.0)\end{array}$ & $\begin{array}{c}2.0 \\
(1.0 \div 2.0)\end{array}$ & $\begin{array}{c}2.0 \\
(0.5 \div 2.0)\end{array}$ & $\begin{array}{c}18.5 \\
(17.5 \div 19.5)\end{array}$ \\
\hline $\begin{array}{l}\text { Hemantane, } \\
20 \mathrm{mg} / \mathrm{kg}\end{array}$ & $\begin{array}{c}1.0 \\
(0.0 \div 2.0)^{*}\end{array}$ & $\begin{array}{c}2.0 \\
(2.0 \div 2.0)\end{array}$ & $\begin{array}{c}2.0 \\
(2.0 \div 2.0)\end{array}$ & $\begin{array}{c}2.0 \\
(2.0 \div 2.0)\end{array}$ & $\begin{array}{c}2.0 \\
(2.0 \div 2.0)\end{array}$ & $\begin{array}{c}1.5 \\
(1.0 \div 2.0)\end{array}$ & $\begin{array}{c}2.0 \\
(1.0 \div 2.0)\end{array}$ & $\begin{array}{c}1.0 \\
(1.0 \div 2.0)\end{array}$ & $\begin{array}{c}0.5 \\
(0.0 \div 2.0)\end{array}$ & $\begin{array}{c}13.5 \\
(12.0 \div 16.0)^{*}\end{array}$ \\
\hline $\begin{array}{l}\text { Amantadine, } \\
20 \mathrm{mg} / \mathrm{kg}\end{array}$ & $\begin{array}{c}1.5 \\
(1.0 \div 2.0)\end{array}$ & $\begin{array}{c}2.0 \\
(1.5 \div 2.0)\end{array}$ & $\begin{array}{c}2.0 \\
(2.0 \div 2.5)\end{array}$ & $\begin{array}{c}2.0 \\
(1.0 \div 2.0)\end{array}$ & $\begin{array}{c}2.0 \\
(1.5 \div 2.0)\end{array}$ & $\begin{array}{c}1.0 \\
(1.0 \div 2.0)\end{array}$ & $\begin{array}{c}1.5 \\
(1.0 \div 2.0)\end{array}$ & $\begin{array}{c}1.5 \\
(1.0 \div 2.0)\end{array}$ & $\begin{array}{c}2.0 \\
(1.0 \div 2.0)\end{array}$ & $\begin{array}{c}15.5 \\
(12.5 \div 17.5)\end{array}$ \\
\hline $\begin{array}{l}\text { Diclofenac } \\
\text { sodium, } \\
10 \mathrm{mg} / \mathrm{kg}\end{array}$ & $\begin{array}{c}1.0 \\
(1.0 \div 1.0)^{*}\end{array}$ & $\begin{array}{c}2.0 \\
(1.0 \div 2.0)^{*}\end{array}$ & $\begin{array}{c}2.0 \\
(2.0 \div 2.0)\end{array}$ & $\begin{array}{c}2.0 \\
(2.0 \div 2.0)\end{array}$ & $\begin{array}{c}1.5 \\
(1.0 \div 2.0)\end{array}$ & $\begin{array}{c}1.0 \\
(1.0 \div 2.0)\end{array}$ & $\begin{array}{c}1.0 \\
(1.0 \div 2.0)\end{array}$ & $\begin{array}{c}1.0 \\
(0.0 \div 2.0)\end{array}$ & $\begin{array}{c}1.0 \\
(0.0 \div 2.0)\end{array}$ & $\begin{array}{c}13.0 \\
(8.0 \div 17.0)^{*}\end{array}$ \\
\hline
\end{tabular}

Data were analyzed by the Kruskal-Wallis test with post-hoc Dunn’s multiple comparison test. Data are expressed as median ( $25 \% \div 75 \%)$. to the control group. 


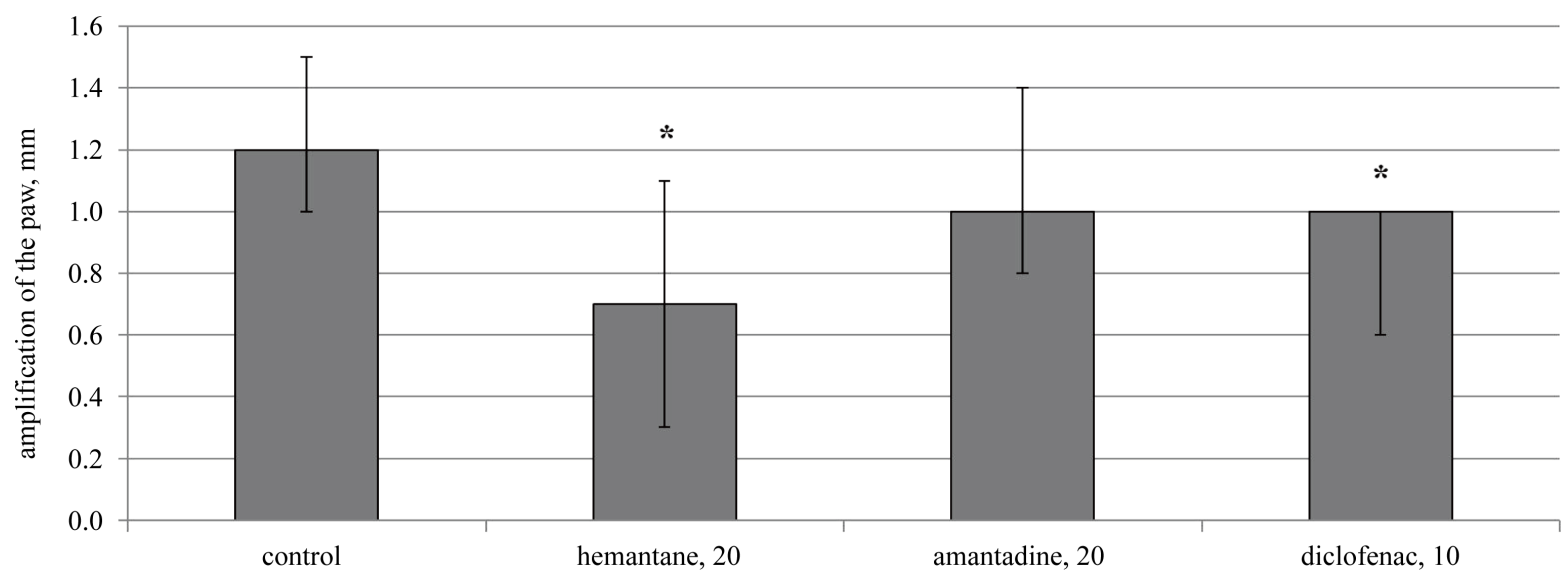

Figure 3. Paw edema in the formalin test. Data were analyzed by the Mann-Whitney test. Data are expressed as median (25\% $\div 75 \%$ ). ${ }^{*} \mathrm{p}<0.05$ compared to the control group.

Table 5. Mass of peritoneal exudate in mice with acetic peritonitis (mg).

\begin{tabular}{clc}
\hline & \multicolumn{2}{c}{ Mass of exudate with different routes of administration } \\
\cline { 2 - 3 } Control, saline & \multicolumn{1}{c}{ intraperitoneally } & orally \\
Hemantane, $20 \mathrm{mg} / \mathrm{kg}$ & $796.0(705.0 \div 968.0)$ & $912.0(746.0 \div 989.0)$ \\
Amantadine, $20 \mathrm{mg} / \mathrm{kg}$ & $535.0(424.0 \div 800.0)^{*}$ & $634.0(434.0 \div 772.0) \#$ \\
Diclofenac sodium, $10 \mathrm{mg} / \mathrm{kg}$ & $648.0(558.0 \div 714.0)^{*}$ & $995.5(787.0 \div 1234.0)$ \\
\hline
\end{tabular}

Data were analysed by the Mann-Whitney test (for non-parametric analysis) and by the Newman-Keuls test (for parametric analysis). Data are expressed as median $(25 \% \div 75 \%)$. ${ }^{*}$ p $<0.05$ compared to the control group, Mann-Whitney test; **p $<0.005$ compared to the control group, Mann-Whitney test; \#p $<0.05$ compared to the control group, Newman-Keuls test; \#\#p $<0.005$ compared to the control group, Newman-Keuls test.

\section{Discussion}

Aminoadamantane derivatives are known to have antinociceptive properties. Memantine, a 1-aminoadamantane derivative and an uncompetitive NMDA receptor antagonist, had an antinociceptive effect in the vincristine- induced peripheral neuropathy model in rats at a dose of $10 \mathrm{mg} / \mathrm{kg}$ [35]. Some derivatives of 1-aminoadamantane are investigated as potential analgesic compounds because of their agonist activity at $\mathrm{CB}_{2}$ or/and $\mathrm{CB}_{1}$ cannabinoid receptors [36] [37]. Replacement of the phenyl ring in molecule of paracetamol (acetaminophen) with an adamantyl moiety produced a new 1-aminoadamantane derivative with analgesic properties that can only be explained by selective TRPA $A_{1}$ channel antagonist activity rather than by COX inhibition or by direct interaction with cannabinoid receptors [38]. Molecules containing 2-aminoadamantane-1-carboxylic acid and 2-aminoadamantane fragments have antinociceptive properties owing to the inhibition of $\mathrm{P}_{2} \mathrm{X}_{7}$-triggered glutamate release [39]. Furthermore, one of the molecules under investigation was tested in the carrageenan paw edema model in rats, exhibiting a capacity to reduce the volume of exudative edema [39].

In our investigation the analgesic properties of two aminoadamantane-class uncompetitive NMDA receptor antagonists were assessed. The analgesic effect of amantadine, a 1-aminoadamantane derivative, differed from the effect of hemantane, a 2-aminoadamantane derivative (Table 6). To wit, both of them exhibited analgesic activity in the tail-flick test in mice when administered i.p.; the effect of amantadine was more pronounced but did not surpass the analgesic activity of carbamazepine (Figure 2). The stronger analgesic action of amantadine is probably best explained by its greater capacity for the inhibition of serotonin reuptake compared to hemantane [40].

Hemantane and amantadine i.p. both exhibited analgesic activity in the test on persistent pain produced by acute inflammation. However, when given orally in the acute thermal pain test and in the acetic acid-induced persistent pain test, hemantane administered 40 minutes before the tests was the only drug to significantly reduce 
Table 6. Influence of hemantane and amantadine on different types of experimental pain*.

\begin{tabular}{|c|c|c|c|c|}
\hline \multirow{3}{*}{ Models of pain } & \multicolumn{4}{|c|}{ Aminoadamantane derivatives and their mode of administration } \\
\hline & \multicolumn{2}{|c|}{ Hemantane, 20 mg/kg } & \multicolumn{2}{|c|}{ Amantadine, $20 \mathrm{mg} / \mathrm{kg}$} \\
\hline & Intraperitoneally & Orally & Intraperitoneally & Orally \\
\hline Acute thermal pain & + & + & + & 0 \\
\hline $\begin{array}{l}\text { Persistent pain produced by } \\
\text { acute inflammation }\end{array}$ & + & + & + & 0 \\
\hline Formalin pain & \multicolumn{2}{|c|}{$\begin{array}{l}\text { Hemantane, } 20 \mathrm{mg} / \mathrm{kg} \\
\text { intraperitoneally }\end{array}$} & \multicolumn{2}{|c|}{$\begin{array}{l}\text { Amantadine, } 20 \mathrm{mg} / \mathrm{kg} \\
\text { intraperitoneally }\end{array}$} \\
\hline The acute early phase of formalin pain & \multicolumn{2}{|l|}{0} & \multicolumn{2}{|l|}{+} \\
\hline The late tonic phase of formalin pain & \multicolumn{2}{|l|}{+} & \multicolumn{2}{|l|}{0} \\
\hline
\end{tabular}

*“+” means significant $(\mathrm{p}<0.05)$ analgesic effect, “0” means absence of significant analgesic effect.

pain. Amantadine should probably be administered earlier before the test to take effect. For example, amantadine was administered subcutaneously $100 \mathrm{~min}$ prior to L-DOPA to demonstrate its anti-dyskinetic activity in the model of L-DOPA-induced dyskinesia in animals [41]-[43]. Remarkably, simultaneous administration of amantadine $20 \mathrm{mg} / \mathrm{kg}$ with levodopa $10 \mathrm{mg} / \mathrm{kg}$ and benserazide $15 \mathrm{mg} / \mathrm{kg}$ i.p. accelerated the onset of LDOPA-induced dyskinesia in rats and increased its severity rather than reducing it [10].

Amantadine produced a pronounced analgesic effect on the acute early phase of formalin pain induced by the action of algogen on the primary sensory afferents [44], but had no impact on the second phase of pain. In contrast, hemantane had no effect on the early phase of formalin pain while reducing the intensity of the late tonic phase of formalin pain mediated by peripheral inflammation [33] [34] (Table 6). The effect of hemantane on the tonic phase of formalin pain was quite similar to diclofenac sodium. The comparator medicine showed an analgesic effect typical for NSAID in this model of pain by only reducing the intensity of the tonic phase of pain. The effect of hemantane $20 \mathrm{mg} / \mathrm{kg}$ on the tonic phase of formalin pain was due to its significant anti-inflammatory activity, which was demonstrated in the tests of acetic peritonitis in mice and formalin paw edema in rats (Table 5, Figure 3). Earlier it was shown that hemantane i.p. at the dosage range $10-40 \mathrm{mg} / \mathrm{kg}$ reduced exudative inflammation in mice with acetic peritonitis but its effect was less pronounced than the effect of diclofenac sodium i.p. $10 \mathrm{mg} / \mathrm{kg}$ [45]. Hemantane i.p. at three doses of 10, 20 and $40 \mathrm{mg} / \mathrm{kg}$ also significantly decreased the pseudoallergic reaction in the model of concanavalin A-induced edema in mice [46]. The mechanism of anti-inflammatory action of hemantane is associated with its capacity to reduce the elevated level of proinflammatory cytokines in blood plasma in mice and rats with experimental pathology [46], and with its antiradical effect [26]. Additionally, it was observed that hemantane reduced elevated proline-specific endopeptidase (EC 3.4.21.26.) activity in the plasma of rats with rotenone-induced Parkinson's disease to the level representative for intact rats [47]. The activity of the enzyme is known to correlate with the level of proinflammatory interleukins in rat models and in cirrhotic patients [48].

Amantadine demonstrated anti-inflammatory activity in the experiments described above only when administered i.p. in the test of acetic peritonitis in mice, and its effect was less pronounced than the anti-inflammatory effect of hemantane (Table 5). According to the literature, amantadine can alleviate local inflammation in the brain tissue of animals with experimental Parkinson's disease. Specifically, amantadine $20 \mathrm{mg} / \mathrm{kg}$ exhibited antiradical activity by reducing the intensity of lipid peroxidation and increasing glutathione content in the substantia nigra of rats with 6-hydroxydopamine-induced Parkinson's disease [49]. This drug reduced lipopolysaccharide- and 1-methyl-4-phenylpyridinium ion (MPP+)-induced toxicity of dopamine neurons through 1) the inhibition of the release of microglial pro-inflammatory factors, 2) an increase in expression of neurotrophic factors such as GDNF from astroglia [50]. Consequently, the anti-inflammatory properties of amantadine and hemantane contribute to their neuroprotective activity. Moreover, as both medicines inhibit NMDA receptors, they could be hypothesized to modulate COX-2 activity, and therefore also inflammation, via NMDA receptors [51]. 


\section{Conclusion}

In summary, our results demonstrate that the analgesic activity of amantadine $(20 \mathrm{mg} / \mathrm{kg})$, a derivative of 1 aminoadamantane, differs from the effect of hemantane $(20 \mathrm{mg} / \mathrm{kg})$, a 2-aminoadamantane derivative. Amantadine was more effective in the model of acute thermal pain in mice. In addition, only amantadine exhibited a significant analgesic effect on the acute early phase of formalin pain in rats induced by the influence of the algogen on the primary sensory afferents. Abatement of pain produced by acute inflammation (the late tonic phase of formalin pain in rats and acetic twitches in mice) was stronger with 2-aminoadamantane hemantane treatment owing to its pronounced anti-inflammatory activity. Differences in the analgesic activity of amantadine and hemantane revealed in this experimental study necessitate further investigations which aim at identifying the underlying pharmacodynamic mechanisms.

\section{References}

[1] Wanka, L., Iqbalb, K. and Schreiner, P.R. (2013) The Lipophilic Bullet Hits the Targets: Medicinal Chemistry of Adamantane Derivatives. Chemical Reviews, 113, 3516-3604. http://dx.doi.org/10.1021/cr100264t

[2] Crosby, N.J., Deane, K. and Clarke, C.E. (2003) Amantadine for Dyskinesia in Parkinson's Ddisease. Cochrane Database of Systematic Reviews, 2, CD003467.

[3] Sawada, H., Oeda, T., Kuno, S., Nomoto, M., Yamamoto, K., Yamamoto, M., Hisanaga, K., Kawamura, T., and for the Amantadine Study Group (2010) Amantadine for Dyskinesias in Parkinson’s Disease: A Randomized Controlled Trial. PLoS ONE, 12, e15298. http://dx.doi.org/10.1371/journal.pone.0015298

[4] Schwab, R.S., England, A.C., Poskanzer, D.C. and Young, R.R. (1969) Amantadine in the Treatment of Parkinson's Disease. JAMA, 208, 1168-1170. http://dx.doi.org/10.1001/jama.1969.03160070046011

[5] Reisberg, B., Doody, R., Stöffler, A., Schmitt, F., Ferris, S., Möbius, H.J., and for the Memantine Study Group (2003) Memantine in Moderate-to-Severe Alzheimer's Disease. The New England Journal of Medicine, 14, 1333-1341. http://dx.doi.org/10.1056/NEJMoa013128

[6] Peskind, E.R., Potkin, S.G., Pomara, N., Ott, B.R., Graham, S.M., Olin, J.T. and McDonald, S. (2006) Memantine Treatment in Mild to Moderate Alzheimer Disease: A 24-Week Randomized, Controlled Trial. The American Journal of Geriatric Psychiatry, 14, 704-715. http://dx.doi.org/10.1097/01.JGP.0000224350.82719.83

[7] Wilcock, G., Möbius, H.J., Stöffler, A., and MMM 500 Group (2002) A Double-Blind, Placebo-Controlled Multicentre Study of Memantine in Mild to Moderate Vascular Dementia (MMM500). International Clinical Psychopharmacology, 17, 297-305. http://dx.doi.org/10.1097/00004850-200211000-00005

[8] Merello, M., Nouzeilles, M.I., Cammarota, A. and Leiguarda R. (1999) Effect of Memantine (NMDA Antagonist) on Parkinson's Disease: A Double-Blind Crossover Randomized Study. Clinical Neuropharmacology, 22, 273-276.

[9] Nerobkova, L.N., Val'dman, E.A., Voronina, T.A., Markina, N.V. and Sharkova, L.M. (2000) Effect of the New Aminoadamantane Derivative A-7 on the Parkinsonism Syndrome Manifestations Induced by the Systemic Administration of MPTP Neurotoxin. Eksperimental'naia i Klinicheskaia Farmakologiia, 63, 3-6.

[10] Kapitsa, I.G., Ivanova, E.A., Nepoklonov, A.V., Kokshenev, I.I., Voronina, T.A. and Val'dman, E.A. (2011) Comparative Study of Amantadine and Hemantane Effects on Development of Levodopa-Induced Dyskinesia in Rat Model of Parkinsonian Syndrome. Eksperimental'naia i Klinicheskaia Farmakologiia, 74, 9-12.

[11] Kornhuber, J., Bormann, J., Hubers, M., Rusche, K. and Riederer, P. (1991) Effects of the 1-Aminoadamantanes at the MK-801 Binding Site of the NMDA Receptor Gated Ion Channel: Human Postmortem Study. European Journal of Pharmacology, 206, 297-300. http://dx.doi.org/10.1016/0922-4106(91)90113-V

[12] Danysz, W., Parsons, C.G., Kornhuber, J., Schmidt, W.J. and Quack, G. (1997) Aminoadamantanes as NMDA Receptor Antagonists and Antiparkinsonian Agents-Preclinical Studies. Neuroscience \& Biobehavioral Reviews, 21, 455468. http://dx.doi.org/10.1016/S0149-7634(96)00037-1

[13] Elshanskaya, M.V., Sobolevskii, A.I., Val'dman, E.A. and Khodorov, B.I. (2001) Interaction of the New Adamantane Derivative A7-A Potential Antiparkinsonian Drug-with NMDA Receptor Channels. Eksperimental'naia i Klinicheskaia Farmakologiia, 64, 18-21.

[14] Danysz, W., Parsons, C.G., Bresink, I. and Quack, G. (1995) A Revived Target for Drug Development? Glutamate in CNS Disorders. Drug News \& Perspectives (DN\&P), 8, 261-277.

[15] Ikeda, H., Heinke, B., Ruscheweyh, R. and Sandkühler J. (2003) Synaptic Plasticity in Spinal Lamina I Projection Neurons that Mediate Hyperalgesia. Science, 299, 1237-1240. http://dx.doi.org/10.1126/science.1080659

[16] Ikeda, H., Stark, J., Fischer, H., Wagner, M., Drdla, R., Jäger, T. and Sandkühler, J. (2006) Synaptic Amplifier of Inflammatory Pain in the Spinal Dorsal Horn. Science, 312, 1659-1662. http://dx.doi.org/10.1126/science.1127233 
[17] Liu, X.G. and Sandkühler, J. (1995) Long-Term Potentiation of C-Fiber-Evoked Potentials in the Rat Spinal Dorsal Horn Is Prevented by Spinal N-Methyl-D-Aspartic Acid Receptor Blockage. Neuroscience Letters, 191, 43-46. http://dx.doi.org/10.1016/0304-3940(95)11553-0

[18] Latremoliere, A. and Woolf, C.J. (2009) Central Sensitization: A Generator of Pain Hypersensitivity by Central Neural Plasticity. The Journal of Pain, 10, 895-926. http://dx.doi.org/10.1016/j.jpain.2009.06.012

[19] Amin, P. and Sturrock, N.D. (2003) A Pilot Study of the Beneficial Effects of Amantadine in the Treatment of Painful Diabetic Peripheral Neuropathy. Diabetic Medicine, 20, 114-118. http://dx.doi.org/10.1046/j.1464-5491.2003.00882.x

[20] Valdman, E.A., Ivanova, E.A., Kapitsa, I.G., Voronina, T.A., Alekseeva, S.V., Nepoklonov, A.V. (2015) A Compound for the Therapy of Pain and Inflammation in Neurodegenerative Diseases. Rus Patent No. 2559777.

[21] Muhlack, S., Müsch, P., Konietzka, S., Woitalla, D., Przuntek, H. and Müller, T. (2010) Impact of Oral Fast Release Amantadine on Movement Performance in Patients with Parkinson's Disease. Pharmaceutics, 2, 313-320. http://dx.doi.org/10.3390/pharmaceutics2030313

[22] Todorovic, S.M., Rastogi, A.J. and Jevtovic-Todorovic, V. (2003) Potent Analgesic Effects of Anticonvulsants on Peripheral Thermal Nociception in Rats. British Journal of Pharmacology, 140, 255-260. http://dx.doi.org/10.1038/sj.bjp.0705434

[23] Caldwell, J.R. (1986) Efficacy and Safety of Diclofenac Sodium in Rheumatoid Arthritis Experience in the United States. The American Journal of Medicine, 80, 43-47. http://dx.doi.org/10.1016/0002-9343(86)90079-3

[24] Akriviadis, E., Hatzigavriel, M., Kapnias, D., Kirimlidis, J., Markantas, A. and Garyfallos, A. (1997) Treatment of Biliary Colic with Diclofenac: A Randomized, Double-Blind, Placebo-Controlled Study. Gastroenterology, 113, 225-231. http://dx.doi.org/10.1016/S0016-5085(97)70099-4

[25] Wober, W. (1999) Comparative Efficacy and Safety of Nimesulide and Diclofenac in Patients with Acute Shoulder, and a Meta-Analysis of Controlled Studies of Nimesulide. Rheumatology, 38, 33-38. http://dx.doi.org/10.1093/rheumatology/38.suppl 1.33

[26] Val'dman, E.A. (2001) Development of a Pharmacologic Medication for the Pathogenic Therapy of Parkinsonism Based on the Analysis of the Mechanisms of Action of Aminoadamantane Derivatives. Habilitation Thesis, Zakusov Institute of Pharmacology, Moscow.

[27] Ivanova, E.A., Nepoklonov, A.V., Kokshenev, I.I., Kapitsa, I.G., Voronina, T.A. and Val'dman, E.A. (2012) Study of Anticataleptic Activity of Hemantane Using Different Routs of Drug Administration and in Combination with Levodopa. Biomedicine, 1, 74-81.

[28] Bhandage, A., Shevkar, K. and Undale, V. (2009) Evaluation of Antinociceptive Activity of Roots of Glycyrrhiza glabra Linn. Journal of Pharmacy Research, 2, 803-807.

[29] Purnima, A., Koti, B.C., Thippeswamy, A.H.M., Jaji, M.S., Vishwantha Swamy, A.H.M., Kurhe, Y.V. and Jaffar Sadiq, A. (2010) Antiinflammatory, Analgesic and Antipyretic Activities of Mimusops elengi Linn. Indian Journal of Pharmaceutical Sciences, 72, 480-485. http://dx.doi.org/10.4103/0250-474X.73908

[30] Voronina, T.A. and Guzevatykh, L.S. (2012) Methodological Instructions on the Study of Drugs' Analgesic Activity. In: Mironov, A.N., Bunatyan N.D., Vasil'ev, A.N., et al., Eds., Guidance on Preclinical Study of New Pharmacological Substances, Part 1, Grif and K, Moscow, 197-217.

[31] Brown, J.H., Kissel, J.W. and Lish, P.M. (1968) Studies on the Acute Inflammatory Response. I. Involvement of the Central Nervous System in Certain Models of Inflammation. Journal of Pharmacology and Experimental Therapeutics, 160, 231-242.

[32] Shvarts, G. Ya. and Syabaev, R.D. (2012) Methodological Instructions on the Study of New Nonsteroidal Anti- Inflammatory Drugs. In: Mironov, A.N., Bunatyan N.D., Vasil'ev, A.N., et al., Eds., Guidance on Preclinical Study of New Pharmacological Substances, Part 1, Grif and K, Moscow, 746-758.

[33] Lee, I.O. and Jeong, Y.S. (2002) Effects of Different Concentrations of Formalin on Paw Edema and Pain Behaviors in Rats. Journal of Korean Medical Science, 17, 81-85. http://dx.doi.org/10.3346/jkms.2002.17.1.81

[34] Bannon, A.W. and Malmberg, A.B. (2007) Models of Nociception: Hot-Plate, Tail-Flick, and Formalin Tests in Rodents. Current Protocols in Neuroscience. http://dx.doi.org/10.1002/0471142301.ns0809s41

[35] Park, B.Y., Park, S.H., Kim, W.M., Yoon, M.H. and Lee, H.G. (2010) Antinociceptive Effect of Memantine and Morphine on Vincristine-Induced Peripheral Neuropathy in Rats. The Korean Journal of Pain, 23, 179-185. http://dx.doi.org/10.3344/kjp.2010.23.3.179

[36] Pasquini, S., Botta, L., Semeraro, T., Mugnaini, C., Ligresti, A., Palazzo, E., Maione, S., Di Marzo, V. and Corelli, F. (2008) Investigations on the 4-Quinolone-3-Carboxylic Acid Motif. 2. Synthesis and Structure-Activity Relationship of Potent and Selective Cannabinoid-2 Receptor Agonists Endowed with Analgesic Activity in Vivo. Journal of Medicinal Chemistry, 51, 5075-5084. http://dx.doi.org/10.1021/jm800552f 
[37] Banister, S.D., Wilkinson, S.M., Longworth, M., Stuart, J., Apetz, N., English, K., Brooker, L., Goebel, C., Hibbs, D. E., Glass, M., Connor, M., McGregor, I.S. and Kassiou, M. (2013) The Synthesis and Pharmacological Evaluation of Adamantane-Derived Indoles: Cannabimimetic Drugs of Abuse. ACS Chemical Neuroscience, 4, 1081-1092. http://dx.doi.org/10.1021/cn400035r

[38] Fresno, N., Pérez-Fernández, R., Goicoechea, C., Alkorta, I., Fernández-Carvajal, A., de la Torre-Martínez, R., Quirce, S., Ferrer-Montiel, A., Martín, M.I., Goya, P. and Elguero, J. (2014) Adamantyl Analogues of Paracetamol as Potent Analgesic Drugs via Inhibition of TRPA1. PLOS ONE, 9, e113841. http://dx.doi.org/10.1371/journal.pone.0113841

[39] Battilocchio, C., Guetzoyan, L., Cervetto, C., Di Cesare Mannelli, L., Frattaroli, D., Baxendale, I.R., Maura, G., Rossi, A., Sautebin, L., Biava, M., Ghelardini, C., Marcoli, M. and Ley, S.V. (2013) Flow Synthesis and Biological Studies of an Analgesic Adamantane Derivative That Inhibits $\mathrm{P}_{2} \mathrm{X}_{7}$-Evoked Glutamate Release. ACS Medicinal Chemistry Letters, 4, 704-709. http://dx.doi.org/10.1021/ml400079h

[40] Zimin, I.A. (2011) Study of the Role of the Serotonergic Component in the Mechanism of Action of the Antiparkinsonian Drug Hemantane. PhD Thesis, Zakusov Institute of Pharmacology, Moscow.

[41] Lundblad, M., Andersson, M., Winkler, C., Kirik, D., Wierup, N. and Cenci, M.A. (2002) Pharmacological Validation of Behavioural Measures of Akinesia and Dyskinesia in a Rat Model of Parkinson's Disease. European Journal of Neuroscience, 15, 120-132. http://dx.doi.org/10.1046/j.0953-816x.2001.01843.x

[42] Dekundy, A., Lundblad, M., Danysz, W. and Cenci, M.A. (2007) Modulation of L-DOPA-Induced Abnormal Involuntary Movements by Clinically Tested Compounds: Further Validation of the Rat Dyskinesia Model. Behavioural Brain Research, 179, 76-89. http://dx.doi.org/10.1016/j.bbr.2007.01.013

[43] Paquette, M.A., Martinez, A.A., Macheda, T., Meshul, C.K., Johnson, S.W., Berger, S.P. and Giuffrida, A. (2012) Anti-Dyskinetic Mechanisms of Amantadine and Dextromethorphan in the 6-OHDA Rat Model of Parkinson's Disease: Role of NMDA vs. 5-HT1A Receptors. European Journal of Neuroscience, 36, 3224-3234. http://dx.doi.org/10.1111/j.1460-9568.2012.08243.x

[44] Hunskaar, S. and Hole, K. (1987) The Formalin Test in Mice: Dissociation between Inflammatory and Non- Inflammatory Pain. Pain, 30, 103-114. http://dx.doi.org/10.1016/0304-3959(87)90088-1

[45] Ivanova, E.A., Kapitsa, I.G., Valdman, E.A. and Voronina, T.A. (2013) The Activity of Antiparkinsonian Drug Hemantane in Models of Peripheral Inflammation and Lipopolysaccharide-Induced Neuroinflammation. Advances in Parkinson's Disease, 2, 11-17. http://dx.doi.org/10.4236/apd.2013.21003

[46] Tallerova, A.V., Ivanova, E.A., Kapitsa, I.G., Kovalenko, L.P., Val'dman, E.A. and Voronina, T.A. (2013) Influence of Antiparkinsonian Drug Hemantane on the Level of Cytokines in Experimental Models. Immunologiya, 5, $254-257$.

[47] Valdman, E., Ivanova, E., Zolotov, N., Kapitsa, I. and Voronina, T. (2015) Effects of Hemantane upon the Activity of Proline-Specific Endopeptidases in Plasma of Rats with Experimental Parkinson's Disease. Intrisic Activity, 3, A2.12.

[48] Tenorio-Laranga, J., Montoliu, C., Urios, A., Hernandez-Rabaza, V., Ahabrach, H., García-Horsman, J.A. and Felipo, V. (2015) The Expression Levels of Prolyl Oligopeptidase Responds Not Only to Neuroinflammation but Also to Systemic Inflammation upon Liver Failure in Rat Models and Cirrhotic Patients. Journal of Neuroinflammation, 12, 183. http://dx.doi.org/10.1186/s12974-015-0404-7

[49] Chattopadhyaya, I., Gupta, S., Mohammed, A., Mushtaq, N., Chauhan, S. and Ghosh, S. (2015) Neuroprotective Effect of Spirulina Fusiform and Amantadine in the 6-OHDA Induced Parkinsonism in Rats. BMC Complementary and Alternative Medicine, 15, 296. http://dx.doi.org/10.1186/s12906-015-0815-0

[50] Ossola, B., Schendzielorz, N., Chen, S.H., Bird, G.S., Tuominen, R.K., Männistö, P.T. and Hong, J.S. (2011) Amantadine Protects Dopamine Neurons by a Dual Action: Reducing Activation of Microglia and Inducing Expression of GNDF in Astroglia. Neuropharmacology, 61, 574-582. http://dx.doi.org/10.1016/j.neuropharm.2011.04.030

[51] Stark, D.T. and Bazan, N.G. (2011) Synaptic and Extrasynaptic NMDA Receptors Differentially Modulate Neuronal Cyclooxygenase-2 Function, Lipid Peroxidation, and Neuroprotection. The Journal of Neuroscience, 31, 13710-13721. http://dx.doi.org/10.1523/JNEUROSCI.3544-11.2011 


\section{Submit or recommend next manuscript to SCIRP and we will provide best service for you:}

Accepting pre-submission inquiries through Email, Facebook, LinkedIn, Twitter, etc.

A wide selection of journals (inclusive of 9 subjects, more than 200 journals)

Providing 24-hour high-quality service

User-friendly online submission system

Fair and swift peer-review system

Efficient typesetting and proofreading procedure

Display of the result of downloads and visits, as well as the number of cited articles

Maximum dissemination of your research work

Submit your manuscript at: http://papersubmission.scirp.org/ 